\title{
Green Consumers and Sustainable Development Goals
}

\author{
Ujang Sumarwan \\ \{sumarwan@apps.ipb.ac.id\} \\ Department of Family and Consumer Sciences, Faculty of Human Ecology, IPB University
}

\begin{abstract}
People and families are components of society that have different parts and capacities, one of which is as buyer. They will devour a assortment of items that will influence the quality of the environment. On the other hand, the quality of the environment will influence the quality of the life of people and families. Subsequently, the people and families play imperative part for keeping up the quality of the environment through utilization exercises. Those who care approximately the affect of utilization exercises are called green customers. The green consumers serve as prerequisite for accomplishing Sustainable Development Goals Number 12, specifically responsible consumption and production. By encouraging ecologically neighborly items, green consumers underwrite makers to satisfy the conditions for the green environment and to encourage them to act in agreement with the maintainability of a solid environment. To teach buyers require the support of different parties, such as families, communities, teachers, makers, non-profit organizations and government. Government approaches ought to address the mindfulness of green consumers.
\end{abstract}

Keywords: green consumers; green environment; consumption activities; sustainable development

\section{Introduction}

One of the most important topics in our session right now is about what we call by the building a green consumer to achieve sustainable development goals this is an area that we are concerned on. Our commitment during 2015 provided the basis to all leaders in the world to overcome about the problem in our society. These problems is documented in our document what we call by sustainable development goal transforming our work: the agenda for sustainable development goal. As we understand that in 2015 the world leader has a commitment to achieve 17 sustainable development goals and 169 targets. Each goal is related to each other, the goals and target in area is critical importance for humanity. As we understand that people, planet, prosperity, peace, and partnership are foundations of Sustainable Development Goals. This morning presentation is very interesting that how women's role in the diplomacy and the power of and the strength of women. I think it is very important to build green consumer by involving women. The SDG will not be achieved successfully without involving the women in the family. This is the area that we have problem for our people to end property and hunger, this is our major problem.

It doesn't matter where you are on this earth we still have poverty and hunger and also we have problem with the environment. We have the problem with ecology how to protect the planet from the degradation and of course we have problem with the people. We have 
problem with the earth and finally we have to ensure that all human beings prosperous. We have also the problem with peace and our main issue is how to foster peaceful just and inclusive society, and overcoming this problem we have to work together. We have to build network so that's why it is important what we call by the partnership to mobilize global resources. We have to highlight the culture in Indonesia what we call by the famous term of Gotong Royong which means work together among community member to help one another, regardless of their races, their religion socio economic status. The Gotong royong also means partnership for mutual assistance to one another. The Covid19 pandemic has became the obstacle and barrier for achieving Sustainable Development Goals. No Nation is ready with the corona virus outbreak. Even in America such City of New York in January 2021 had problem with the capacity of hospital. You can imagine how is the largest country in the world, the strongest country and the biggest economic country they have problem with the hospital capacity. When pandemic is coming we are not ready to face that kind of problems.

\section{Results and Discussion}

\subsection{Sustainable Development Goals (SDG)}

The Sustainable Development Goals have 17 objectives to be accomplished from no destitution, no starvation, wellbeing and well-being, gender orientation correspondence and so on. Past moderator has talked about approximately gender orientation balance in Indonesia which is still the hot issue in our society. My introduction centers on the maintainable improvement objective related to customer and promoting whic is my ability and region of intrigued. The number $12 \mathrm{SDG}$ objective is mindful utilization and generation, and number eight of objective is better than average work and financial development. I will not conversation around the conventional work and financial development, I center on the 12th objective which is mindful utilization and generation. Who are capable for the accomplishment of Objective No 12.

Numerous individuals have misconception that the accomplishments of SDG are government obligations. But this can be not genuine. All component of sociesties are capable for the accomplishment of SDG Goals. A person, a family, community, college, schools, social and trade organization, and government have obligation to do numerous things to attain SDG. Whether separately or socially we are mindful to realize the economical advancement goals. Whether we are within the organization or whether we are within the university or we are within the government. we play major role as consumers because we decide every day what we have to buy what we have to consume, and what we have to deliver to others.

\subsection{The Impact of Consumer and Household on National Economy}

As a consumer, our behavior has significant impact on one or more sustainable development goals. All the actors have major impact on the achievement of SDG through their consumption and production activities. Private companies especially they do their activities on the production side. Private companies also act as consumer because they buy and consume different kinds of goods and services. Each of us who attend this seminar are all consumers. Family and its members are consumer who make decision everyday to buy and to consume 
goods and services. Families and their members are the small entity of the social unit, so all the families make a society and all the society makes the nation. The nation and family and their members are major contributors to the national economics. How ever, their consumption activities directly and indirectly have significant impact on the environment. This is our major concern right now, what consumer buy what consumer consume and what family consume even the private companies consume different kind of goods and services, they have significant impact on the environment.

An Individu, family, and community and institution as consumers, they do activities every day. Even every day, one of us at least buying something or going to other place to find some kind of good or services. The data coming from the Office of Statistic Republic of Indonesia, what is interesting here? This data represents monthly per capita expenditure of cigarettes also monthly expenditure of eggs and milk and vegetables. Monthly expenditure for cigarettes is double than egg and milk expenditure, even larger than buying vegetables. As we understand nobody says that cigarette is good for your health and good for well-being, so this is the problem here our community. even our leaders you know. The smoking habits are found in different characteristics of consumers in Indonesia: young and old, low and high education, low and higher income level, ordinary and public figures. The challege is how to educate consumer to reduce or even to stop tobacco consumption. In the long run smoking habits will have negative impact on the health status of consumer. Public spending on medical expenses will increase the health and well-being of consumer will be worse off. The survey statistics showed that monthly average expenditure per capita for tobacco consumption in rural and urban consumers are relatively the same. Urban and rural consumer have the same smoking habits, they like smoking. Health problems due to smoking habits will appear in the long run in urban and rural areas in Indonesia.

The statistical data on Indonesian Gross Domestic Product showed that Indonesia is the 16th ranks among all the nations in the world. The GDP is one of the indicators of the economic power of the nation. The GDP measured spending or expenditures from different sector of spending unit: households and government. Household and government contributed to the power of economics in the nation. Households contributed about 56 percent of gross domestic product coming from household consumption expenditures. This is the power of consumer, and the power of family and household the power of family. Each member of family spends more money to the economy, and this indicates the power of national economy. In 2019 the GDP of Indonesia is about 15.8 thousands Trillions Rupiah. Indonesia is the 16th ranking in the world. In the next 10 to 15 years Indonesia will be probably top 10 in the GDP world. What is the impact consumption on the environment? we have problem here with the forest degradation, air pollution, food waste, food loss.

\subsection{The Impact of Consumption on the Environment}

A lot of YouTube content talk about the ecological problems, such as household waste. In most cities in Indonesia, household wastes were found in any place. YouTube contents also present many problems with forest degradation. Forest areas became smaller. We have to pay more attention on the household wastes, industrial wastes, and forest degradation. There are many other ecological problems that need to pay attention, such as air pollution, water sanitation and availability, and renewable energy.

Because of the importance of consumption and production activities and the impact on the environment, so the consumption and production as one of the goals that must be achieved in the SDG. All of us understand that consumption activities become one of the major problems 
directly and indirectly influence negatively to the environment. This is some ideas about a detailed explanation about the responsible consumption. First, how we have to use efficient use of natural resource. Second, reduce food loss along production supply chain including post harvest. We can imagine, if a member of a family, he or she left one gram of rice in his or her plate and let's say there are five members so every day at least we left about five grams. Therefore five millions families will have five million grams of rice wastes, which is equal to $5000 \mathrm{~kg}$ of rice or 5 tons of rice per day. For a mont, we loss 150 tons of rice or equal 1800 tons of rice wastes per year. This is a big of loss of rice.

The third item of responsible consumption and production is to achieve the environmentally sound management of chemical. This is what we call by responsible consumption and production and reduce waste generation through prevention, reduction, recycling and reuse. We have to campaign more about what we call by 3 principles of sustainable environment: reduce reuse, and recycle with zero waste. The responsible consumption also mean to achieve the efficient use of natural resources. The sustainable consumption is the consumption of goods and services that have minimal impact on the environment. The key word is the have minimum impact because we cannot make it zero impact but at least minimum impact on the environment and especially equitable and economically valuable meeting the basic need of human worldwide so sustainable consumption target is everyone. Each individual across all sectors and all nations from, the individual to the government and to the multinational conglomerates are responsibles to make program and activities to achieve responsible consumption and production.

The sustainable production what does it mean? It is the creation of goods and services using process and system that are non-polluting, conserving of energy and natural resources, economically available, safe and helpful for workers, communities, and consumers and of course socially and creatively rewarding for all working people. So when the production is sustainable then the environment employees, communities and organization, all get benefit so this condition can lead always in the long term and open in the short term to more economically feasible and productive. It emphasizes that these are like two sides of coin: production and consumption so responsible consumption as well as responsible production and it will lead to the sustainable production.

\subsection{Being Green Consumers to Achieve Responsible Consumption and Production}

So how to implement and to achieve responsible consumption and production? Individuals, families, communities also institution have a responsibility to realize the SDG to the achievement of responsible consumption and production. What we have to do is each of us together with others can contribute to achieving responsible consumption and production by what we have to do by becoming: being what we call by the green consumer, so being green consumer means you take a small step but to achieve larger objectives of responsible consumption and production.

Green consumer is defined as The Ecologically Conscious Consumer and Environmentally Friendly Consumer. Green consumers can be seen consumer mindset as a reaction to consumer concern for a good environment. Green Consumers are consumers who are concerned about the environment. Green consumers are Consuming products that have no negative impact at all. Green Consumer are adopting environmentally friendly behavior and/or purchasing green products over standard alternatives. Green consumers are Interested in product characteristics such as recyclability and chemical content. Green consumers show their concern for the environment and behave environmentally friendly by choosing 
environmentally friendly products they consume. Green consumers want to show their attitudes and behavior. Green consumers adhere to environmentally friendly principles and are proven by their consistent environmentally friendly behavior. Be A Green Consumer, then we are really implementing the real program to achieve the SDG No 12 Responsible Consumption and Production.

\subsection{Other Concepts Related to Green Consumers}

There are some other cocepts which are related to green consumers: green economy, bioeconomy, green manufacturing, green production, green building, sustainable, sustainable agriculture, sustainable consumption, sustainable production, organic agriculture, organic farming. Here are some definitions of the concepts which are direct quotation from their sources. A green economy made goods and services by using low and efficient energy and campaigning for inclusive society. While the bioeconomy is the process of producing, utilizing, and conserving the biological resources to achieve sustainable economy ((Global Bioeconomy Summit, 2018).

What is Green Manufacturing? Green marketing is the process of production which reduce the negative impacts on environtment. Manufactures are encouraged to use less resources, and apply the $3 \mathrm{R}$ principle and zero waste (Reduce, Reuse, Recycle) of resources and Zero Waste (Source: https://www.goodwin.edu/enews/what-is-green-manufacturing/). The green is strongly related to ecology so all activities wth green tag signals are all environmentally friendly. (Source: https://www.inc.com/encyclopedia/green-production.html)

What is green building? A 'green' building could be a building that, in its plan, development or operation, decreases or kills negative impacts, and can make positive impacts, on our climate and common environment. Green buildings protect valuable common assets and progress our quality. of life. There are a number of highlights which can make a building 'green'. These incorporate: Productive utilize of vitality, water and other assets, Utilize of renewable vitality, such as sun oriented vitality, Contamination and squander lessening measures, and the empowering of re-use and reusing, Great indoor natural discuss quality, Utilize of materials that are non-toxic, moral and maintainable, Thought of the environment in plan, development and operation, Thought of the quality of life of tenants in plan, development and operation, A plan that empowers adjustment to a changing environment. (Source https://www.worldgbc.org/what-green-building)

What is a sustainable agriculture? This is a definition of Sustainable Agriculture which is quoted directly from (Source: https://nifa.usda.gov/topic/sustainable-agriculture). Farming frequently places noteworthy weight on common assets and the environment. Economical agrarian hones are planning to secure the environment, extend the Earth's normal asset base, and keep up and make strides soil richness. Based on a multi-pronged objective, economical agribusiness looks for to:

a. Increase beneficial cultivate income

b. Promote natural stewardship

c. Enhance quality of life for cultivate families and communities

d. Increase generation for human nourishment and fiber needs

e. Importance of Economical Agriculture

f. Sustainable agribusiness regularly includes a 
wide extend of generation hones, counting customary and natural. A territorially coordinates framework of plant and creature generation hones are planned to create long-term comes about such as:

g. Production of adequate human nourishment, bolster, fiber, and fuel to meet desires of a strongly rising population

h. Protection of the environment and extension of the common assets supply

i. Sustainment of the financial practicality of horticulture systems

(Source: https://nifa.usda.gov/topic/sustainable-agriculture)

FAO defined "Organic Agriculture may be a all-encompassing generation administration framework which advances and improves agro-ecosystem wellbeing, counting biodiversity, organic cycles, and soil natural movement. It underlines the utilize of administration hones in inclination to the utilize of off-farm inputs, taking under consideration that territorial conditions require locally adjusted frameworks. This can be fulfilled by utilizing, where conceivable, agronomic, organic, and mechanical strategies, as contradicted to utilizing manufactured materials, to satisfy any particular work inside the framework." (FAO/WHO Codex Alimentarius Commission, 1999). (Source: http://www.fao.org/organicag/oa-faq/oafaq $1 /$ en/)

Organic Farming is defined as (direct quotation from http://www.omafra.gov.on.ca/english/crops/facts/09-077.htm) Organic farming could be a strategy of edit and animals generation that includes much more than choosing not to utilize pesticides, fertilizers, hereditarily adjusted organisms, antibiotics and development hormones. Natural generation may be a all-encompassing framework outlined to optimize the efficiency and wellness of different communities inside the agro-ecosystem, counting soil living beings, plants, animals and individuals. The central objective of natural generation is to create endeavors that are feasible and agreeable with the environment. (http://www.omafra.gov.on.ca/english/crops/facts/09-077.htm).

\section{Conclusions}

Busines persons and corporations conducted green economy, bioeconomy, green manufacturing, green production and constructed green building. Food producers and farmers practiced organic agriculture and organic farming. They did the green activities are for the purpose of sustainable environment and producing green products and to meet the demand of green products by green consumers. In can be concluded that producing green products are the reactions of companies and business persons to meet the demand of green consumers for green products that are environmentally friendly

\section{References}

[1] da Silva Tamashiro, H.R., da Silveira, J.A.G., Merlo, E.M., Ghisi, M. (2013). Ecologically-Conscious Consumer Purchases in Lithuania. Tamuliene, Vilma; Kazlauskiene, Egle; Pileliene, Lina. Montenegrin Journal of Economics; Podgorica Vol. 12, Iss. 4, (2016): 87-96. "The relationship be- tween ecological knowledge, 
ecological concern, ecological affection, subjective norms and the green purchase behavior in Brazil", African Journal of Business Management, Vol. 7, No. 34, pp. 3297-3314.

[2] da Silva Tamashiro, H.R., da Silveira, J.A.G., Merlo, E.M., Ghisi, M. (2013), “The relationship be- tween ecological knowledge, ecological concern, ecological affection, subjective norms and the green purchase behavior in Brazil", African Journal of Business Management, Vol. 7, No. 34, pp. 3297-3314.

[3] Akehurst, G., Afonso, C., Goncalves, H.M. (2012), "Re-examining Green Purchase Behaviour and the Green Consumer Profile: New Evidences“, Management Decision Vol. 50, No. 5, pp. 972-988.

[4] Elkington, J. and Hailes, J. (1989). The Green Consumer's Supermarket Shopping Guide, Gollancz, London.

[5] Luzio JPP, Lemke F. 2013. Exploring green consumers'product demands and consumption processes: The case of Portuguese green consumers. European Business Review Vol. 25 No. 3, pp. 281-300

[6] Abraham, N. (2011), "The apparel aftermarket in India-a case study focusing on reverse logistics”, Journal of Fashion Marketing and Management, Vol. 15 No. 2, pp. 211-227.

[7] Canning, L. (2006), "Rethinking market connections: mobile phone recovery, reuse and recycling in the UK", Journal of Business and Industrial Marketing, Vol. 21 No. 3, pp. 320-329.

[8] Hartmann, P. and Ibanez, V.A. (2006), "Green value added", Marketing Intelligence and Planning, Vol. 24 No. 7, pp. 673-680.

[9] Elkington, John. 1994. Towards the Sustainable Corporation: Win-Win-Win Business Strategies for Sustainable Development

[10] Sachin S. Vernekar, Preeti Wadhwa. 2011. Green Consumption An Empirical Study of Consumers Attitudes and Perception regarding Eco-Friendly FMCG Products, with special reference to Delhi and NCR Region Abstract

[11] Leonidas C. Leonidou, Constantinos N. Leonidou, Dayananda Palihawadana, Magnus Hultman. 2011. Evaluating the green advertising practices of international firms: a trend analysis. International Marketing Review .ISSN: 0265-1335. Publication date: 22 February 2011

[12] Leonidas C. Leonidou , Constantinos N. Leonidou \& Olga Kvasova . 2010. Antecedents and outcomes of consumer environmentally friendly attitudes and behaviour. Journal of Marketing Management, Volume 26, 2010 - Issue 13-14: Academy of Marketing Conference 2010, “Transformational Marketing” .Pages 13191344 | Published online: 06 Dec 2010. https://doi.org/10.1080/0267257X.2010.523710

[13] Lazer, W. (1969), "Marketing's changing social relationships", Journal of Marketing, Vol. 33 No. 1, pp. 3-9.

[14] Lazer, W. (2013), "Marketing's changing social relationships: a retrospective", Social Business, Vol. 3 No. 4, pp. 325-343.

[15] Prashant Kumar, T.A. Pai Management Institute, Manipal, India. Marketing Intelligence \& Planning Vol. 34 No. 1, 2016 pp. 137-158, 5

[16] Zhu, Q., Sarkis, J. and Lai, K.-H. (2013), "Institutional-based antecedents and performance outcomes of internal and external green supply chain management practices", Journal of Purchasing and Supply Management, Vol. 19 No. 2, pp. 106-117. 
[17] Holt, D. and Ghobadian, A. (2009), "An empirical study of green supply chain management practices amongst UK manufacturers", Journal of Manufacturing Technology Management, Vol. 20 No. 7, pp. 933-956.

[18] Pujari, D. and Wright, G. (1996), "Developing environmentally conscious product strategies: a qualitative study of selected companies in Germany and Britain", Marketing Intelligence and Planning, Vol. 14 No. 1, pp. 19-28.

[19] Pujari, D., Wright, G. and Peattie, K. (2003), "Green and competitive influences on environmental

[20] new product development performance", Journal of Business Research, Vol. 56 No. 8, pp. 657-671.

[21] http://www.tokopedia.com/hot/beras-organik, 8

[22] http://www.fao.org/energy/bioeconomy/en, 17

[23] http://www.fao.org/organicag/oa-faq/oa-faq1/en/, 20h

[24] http://www.gdrc.org/sustdev/concepts/22-s-consume.html, 19

[25] http://www.omafra.gov.on.ca/english/crops/facts/09-077.htm, 21

[26] http://www.wf-npt.com/products2/2017-10-10/1551.html, 14

[27] https://dictionary.cambridge.org/dictionary/english/green-consumer, 1

[28] https://en.wikipedia.org/wiki/List of fuel cell vehicles, 14

[29] https://en.wikipedia.org/wiki/List_of_solar-powered_products, 10

[30] https://familydoctor.org/herbal-health-products-and-supplements/, 12

[31] https://nifa.usda.gov/topic/sustainable-agriculture, 18

[32] https://polacup.com/kemasan-kertas-daur-ulang/, 8

[33] https://www.blibli.com/jual/solar-water-heater/, 11

[34] https://www.collinsdictionary.com/dictionary/english/sustainable, 18

[35] https://www.eesi.org/topics/bioenergy-biofuels-biomass/description, 13

[36] https://www.feedough.com/green-product/, 6

[37] https://www.goodwin.edu/enews/what-is-green-manufacturing, 17

[38] https://www.google.com/search? $\mathrm{q}=$ biogas + cooker+brands\&tbm=isch\&source=univ\&s afe $=$ strict\&sa $=$ X\&ved $=2$ ahUKEwiaitDOwYToAhXUQ30KHeBPD9IQ7Al6BAgIEBk $\&$ biw $=1707 \&$ bih $=766 \&$ dpr $=1.13,15$

[39] https://www.healthline.com/nutrition/what-is-organic-food\#section1, 6

[40] https://www.homebiogas.com/Blog/142/What_is_Biogas\%7Cfq\%7C_A_Beginners_G uide, 13

[41] https://www.inc.com/encyclopedia/green-production.html, 17

[42] https://www.sayurbox.com/search?query=organik, 7

[43] https://www.tokopedia.com/hot/beras-organik, 8

[44] https://www.uml.edu/research/lowell-center/about/sustainable-productiondefined.aspx, 19

[45] https://www.undp.org/content/undp/en/home/sustainable-development-goals.html, 20

[46] https://www.unenvironment.org/regions/asia-and-pacific/regionalinitiatives/supporting-resource-efficiency/green-economy, 16

[47] https://www.worldgbc.org/what-green-building, 17

[48] http://www.fao.org/energy/bioeconomy/en/, 17

[49] https://www.inc.com/encyclopedia/green-production.html, 17 